\title{
Self-esteem in children with facial paralysis: A review of measures
}

\author{
Martin Jugenburg BSc, Pam Hubley RN MSc NP, Holly Yandell RN MSc NP, \\ Ralph T Manktelow MD FRCPC, Ronald M Zuker MD FRCPC FACS FAAP \\ Division of Plastic Surgery, The Hospital for Sick Children and The University Health Network, \\ Toronto, Ontario
}

\begin{abstract}
M Jugenburg, P Hubley, H Yandell, RT Manktelow, RM Zuker. Self-esteem in children with facial paralysis: A review of measures. Can J Plast Surg 2001;9(4):143-146.

Research in surgery has traditionally focused on quantitative results, sometimes ignoring the qualitative impact on patients. The purpose of the present review was to identify appropriate measurement tools to assess the psychosocial domains of children undergoing corrective surgery for facial paralysis. More specifically, the construct of self-esteem was explored. The outcome of the present investigation is the recommendation for Harter-based assessment tools for research purposes and the Rosenberg Self-Esteem Scale for clinical use. Using these tools will allow health care professionals to assess the psychosocial issues that are important to children with facial differences and to conduct research on the psychosocial impact of corrective surgery.
\end{abstract}

Key Words: Assessment; Facial paralysis; Self-esteem

\section{L'estime de soi chez les enfants atteints de paralysie faciale : examen des outils d'évaluation}

RÉSUMÉ : La recherche en chirurgie met traditionnellement l'accent sur les résultats quantitatifs, allant même parfois jusqu'à négliger les conséquences qualitatives pour les patients. La présente étude a pour but de trouver des outils de mesure appropriés, permettant d'évaluer les aspects psychosociaux des enfants qui subissent une intervention chirurgicale correctrice pour de la paralysie faciale. Plus précisément, nous avons exploré le volet de l'estime de soi. Nous en sommes arrivés aux conclusions suivantes : les meilleurs outils d'évaluation sont ceux fondés sur le modèle d'Harter pour la recherche et sur l'échelle de l'estime de soi de Rosenberg en clinique. Ces outils permettront aux professionnels de la santé d'évaluer les aspects psychosociaux qui revêtent de l'importance pour les enfants présentant des différences faciales et de faire de la recherche sur l'incidence psychosociale de la chirurgie correctrice.

$\mathrm{S}_{\mathrm{n}}^{\mathrm{e}}$ ff-esteem is a basic human need necessary for achievement (1), the main driving force behind all human activity and an organizing principle on which personal theories of reality are constructed (2). It operates, in effect, as an immune system of consciousness, providing resistance, strength and a capacity for regeneration $(3,4)$. Its absence lowers selfconfidence and increases the likelihood of avoidant social behaviour (5). Thus, a lack of self-esteem impairs one's ability to become a successful member of society $(6,7)$.

Traditionally, surgical research has focused on quantifi- able outcomes such as morbidity and mortality rates, and functional outcomes. Qualitative aspects of surgical procedures, however, have received much less attention. The question addressed in the present article is, in addition to functional improvement, does restoration of facial expression improve patients' general state of happiness, as reflected in self-esteem (8). The purpose of the present review was to identify which of the published self-esteem assessment tools is most appropriate for children with facial paralysis and the pediatric population in general.

Correspondence: Dr RM Zuker, Divison of Plastic Surgery, The Hospital For Sick Children, Toronto, Ontario M5G 1X8. Telephone 416-813-6447, fax 416-813-6147, e-mail ronald.zuker@sickkids.ca 
TABLE 1

Self-esteem assessment tools for children

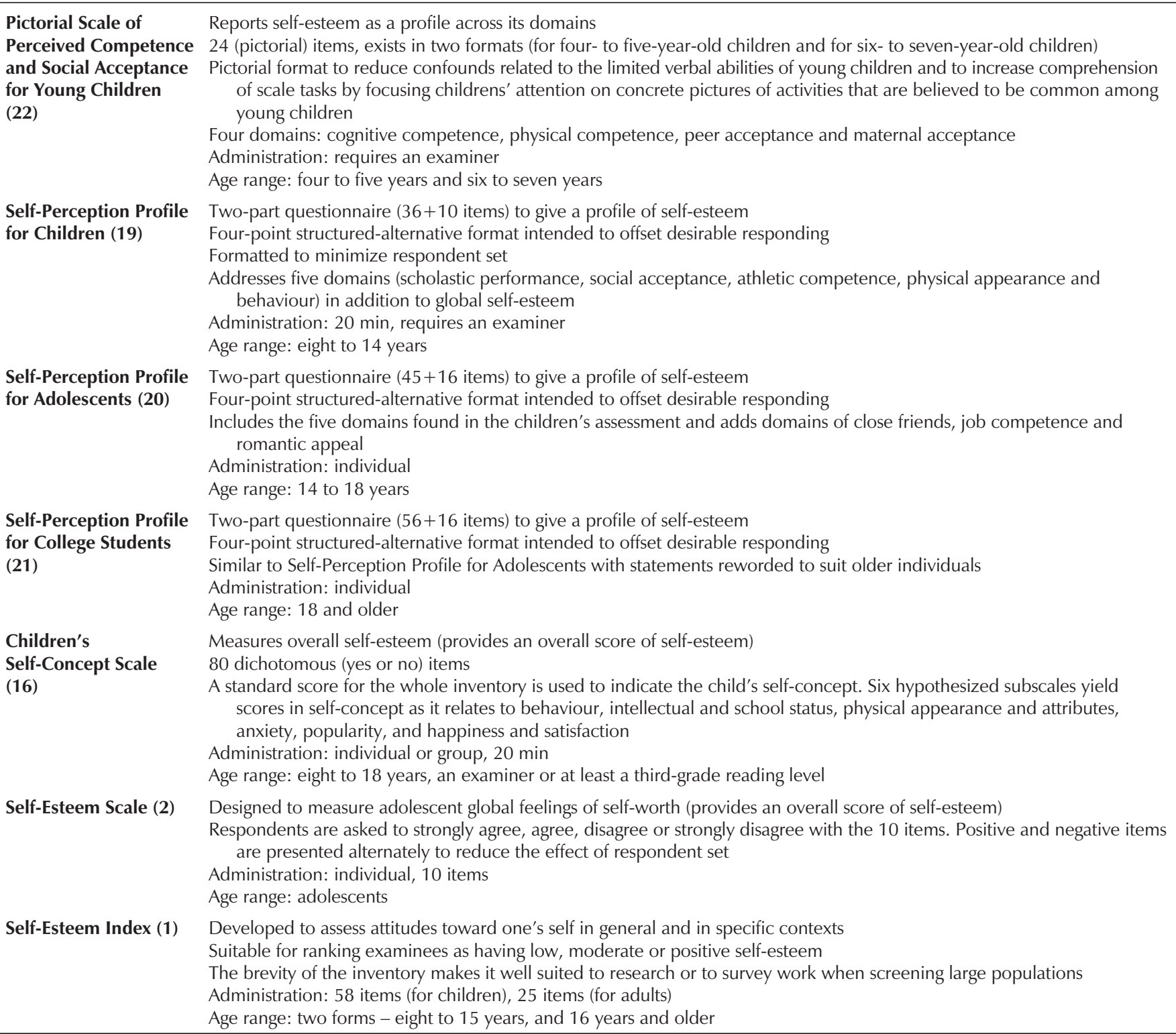

References appear in parentheses

\section{ISSUE DEFINITION}

The present study adopted the following definition of selfesteem. Self-esteem involves a person's positive and negative self-evaluations (2), involving domains with varying importance. High self-esteem includes feelings of self-worth, power and the belief that one's self is competent to cope with the challenges of life and deserves happiness (6). Low selfesteem is defined as a feeling of worthlessness, with a negative impact on social interactions and a decreased resistance to psychological stressors.

\section{METHODS}

A search of MEDLINE, HealthSTAR and other Internet databases, and published texts on assessment tools was completed, and specific self-esteem and quality of life assessment tools were identified and reviewed. Key words used for the searches included 'self-esteem', 'assessment', 'body image', 'self-perception' and 'facial paralysis'. The next step was to identify any assessment tool that could be applicable to a pediatric population. Several tools were identified; however, those that were not thoroughly peer-reviewed for reliability and validity were not analyzed.

\section{RESULTS}

Several tools have been used in the recent literature (9-12), and of those, the ones most widely used and applicable to children were selected and analyzed (Table 1).

The Coopersmith Self-Esteem Inventory (SEI) (1) is a widely used, brief assessment tool that allows for survey work when screening large populations. Consisting of two 
forms, 58 items on a school form and 25 items on an adult form, it ranks examinees as having low, moderate or positive self-esteem. The result is an overall score rather than a profile of self-esteem. The SEI may be a useful tool for school settings (13), provided that its limitations of complexity and measurement of several characteristics in addition to selfesteem are understood.

The Rosenberg Self-Esteem Scale (2) uses a 10-item Likert Scale, has high reliability and scalability, was developed to be a brief tool, and is easy to administer and evaluate. Its brevity is highly practical for a clinical setting. It is highly adaptable to suit specific conditions $(14,15)$. It has satisfactory reproducibility $(92 \%)$ and scalability $(72 \%)$. The scale is internally reliable and appears to have face validity, with better construct and convergent validity than that of the SEI (12). The tool alternates 'positive' and 'negative' items in order to reduce the effect of respondent set.

The Piers-Harris Children's Self Concept Scale (16) is a 20 min self-report instrument aimed at children aged 9 to 18 years. This tool has been used previously for the purpose of assessing children with facial deformities $(17,18)$. It is an 80-item test assessing six aspects of a child's selfesteem: behaviour, intellectual and school status, physical appearance and attributes, anxiety, popularity, and happiness and satisfaction. Items are written at a third-grade reading level in simple declarative statements (eg, 'I am a happy person') and require a yes or no answer. At least one-half of the statements are negative in content to reduce the effects of acquiescence.

Harter tools are a series of measures developed for different age groups: the Self-Perception Profile for Children (19), the Self-Perception Profile for Adolescents (20), the SelfPerception Profile for College Students (21), as well as two versions of the Pictorial Scale of Perceived Competence and Social Acceptance for Young Children (22). These tools generally consist of two parts to the questionnaire: 'What I am like' and 'How important are these things to how you feel about yourself as a person?'. Items provide children with two somewhat opposing indirect and nonthreatening statements; the children first choose which statement describes them best, and then they choose whether the statement is 'Sort of true for me' or 'Really true for me'. The Harter Scale for Teens is of a similar format to the questions in the questionnaire for younger children, except the questions have been adjusted for an older age group. The downward extension of the original scale for children aged four to six, and seven to eight years (Pictorial Scale of Perceived Competence and Social Acceptance for Young Children) (22) has been converted from a text questionnaire to a pictorial questionnaire of 24 items. The assessment tool is introduced as a picture game called 'Which Girl/Boy is the Most Like Me', with pictures illustrating opposing situations. In contrast to text questionnaires, the pictorial format engages the young child's interest, is understandable, sustains the child's attention and leads to more meaningful responses. The pictorial format also allows one to depict skills and specific activities concretely.

\section{DISCUSSION}

While the functional outcome of surgery can be easily examined, its impact on the self-esteem of patients has not been studied thoroughly. Due to the complexity and the abstract nature of self-esteem, and to the lack of widely accepted assessment tools, there will always be a debate over how to best measure self-esteem.

Earlier tools such as the Coopersmith (1) and Piers-Harris (16) scales have sought to assess self-esteem through the calculation of a single score. In contrast, Harter's approach is based on a model of self-concept that represents an integration of two different approaches that have evolved in the self-concept and/or self-esteem literature. On the one hand, self-concept is seen as a unidimensional construct best assessed by combining an individual's self-evaluations across a range of issues. On the other hand, self-esteem is seen to depend on distinctions that individuals make about their competence in different domains of their lives. Harter's assessment of general self-esteem results from the relationship between one's competence and how important that competence is to the person. According to this conceptualization, the failure to achieve domain-specific competence has a negative impact on overall self-esteem, but only in those domains in which success is important. It is an approach that has been accepted in numerous studies, and has yielded a better understanding of children's behaviour $(23,24)$.

A major issue in the assessment of children is the ageappropriateness of tools. Unlike assessment tools for adults, an assessment tool designed for children must be able to address various levels of maturity. The Rosenberg Self-Esteem Scale (2) and SEI (1) are not suitable for children under eight years of age. The Piers-Harris Children's Self-Concept Scale (16) attempts to address this issue by making its items easy to understand, especially in the presence of an interviewer. Although it has been used previously in assessments of children with facial deformities $(17,18)$, its limitation is that it requires a minimum of grade three reading skills. Harter's approach to this problem is to devise a set of essentially similar instruments for the different age groups. The questionnaires for children over the age of eight years are of very similar format with items adjusted to reflect differences in the maturity level of the respondents. Harter uses pictorial scales for children under the age of eight years. The advantage of the pictorial format is that it is easily understood by children and is presented in an interest-stimulating fashion (25-27).

An additional concern that must be considered for all tools is bias and error. All assessment procedures are subject to variations (measurement error) that must be taken into account when drawing conclusions about behavioural and emotional functioning. There is a higher tendency to give socially desirable answers among younger children (22). To combat this natural tendency, Harter scales give children the permission to choose the half of a two-part item that is most like them and to rate whether the chosen half is just 'sort of true' or 'really true'. The opposite of socially desirable answers, 'faking bad' (exaggerating symptoms), is usually interpreted either as a bid for attention or as advice to get out 
of some unwanted situation. Because children are less knowledgeable about any benefits that they may acquire as a result of presenting an unfavourable picture of themselves, it is likely that low scores on a self-esteem evaluation represent a true reflection. In general, while one cannot assume that all high scores reflect truly positive self-esteem, it is most likely that low scores represent the absence of positive self-esteem.

\section{CONCLUSIONS}

Based on the results of the present review, the authors recommend that health care workers use the Harter set of assessments for research purposes. These assessments apply to a wider age range and are able to measure global self-esteem, as well as its domains. The results are reported as a profile of self-perception across the various domains, rather than giving a final, single score on self-esteem. The Rosenberg SelfEsteem Scale and the Piers-Harris Scale were the two runners-up because the first is brief and the latter is well respected. For clinical settings in which brevity of an assessment tool is important, the Rosenberg Self-Esteem Scale is well suited.

ACKNOWLEDGEMENTS: The authors acknowledge the support, guidance and assistance of Dr Lefebvre, Dr McKneally and Mrs Angela Mathers.

\section{REFERENCES}

1. Coopersmith S. The antecedents of self-esteem. California: Consulting Psychologists Press, 1981. (Original work published 1967)

2. Rosenberg M. Society and the Adolescent Self-Image. Princeton: Princeton University Press, 1965.

3. Kernis M, Waschull S. The roles of stability and level of self-esteem in self enhancement and self protective strategies. Adv Exp Soc Psychol 1995;27:108-27.

4. Turner L, Pickering S, Johnson R. The relationship of attributional beliefs to self-esteem. Adolescence 1998;33:477-85.

5. Verkuyten M. Intergroup evaluation and self esteem motivations: self enhancement and self protection. Eur J Soc Psychol 1997;27:115-9.

6. Bednar R, Wells M, Peterson S. Internal and external feedback: basic assumptions. In: Bednar R, ed. Self-Esteem: Paradoxes and Innovations in Clinical Theory and Practice. Washington: American Psychological Association, 1989.

7. Brockner J. Self-esteem and behavioural plasticity. In: Brockner J, ed. Self-Esteem at Work: Research, Theory and Practice. Toronto: Lexington Books, 1988

8. Meyers DC. The Pursuit of Happiness: Who is Happy - and Why.
New York: William Morrow, 1992.

9. Achenbach TM, Edelbrock C. Manual for the Child Behavior Checklist and Revised Child Behavior Profile. Burlington: University of Vermont, 1983.

10. Achenbach TM. The Achenbach System of Empirically Based Assessment. $<$ http://aseba.uvm.edu/front.html $>$ Version current at May $18,2001$.

11. Byrne BM. Measuring Self-Concept across the Life-Span. Washington: American Psychological Association, 1996.

12. Blascovich J, Tomaka J. Measures of self-esteem. In: Robinson JP Shaver PR, Wrightsman LS, eds. Measures of Personality and Social Psychological Attitudes, vol 1. San Diego: Academic Press, 1991.

13. Wellingham-Jones P. Evaluation of adolescents' self-esteem through the Coopersmith Self-esteem Inventory and graphometric analysis of students' handwriting. Percept Mot Skills 1987;65:471-80.

14. Lange A, Kooiman K, Huberts L, van Oostendorp E. Childhood unwanted sexual events and degree of psychopathology of psychiatric patients: research with a new anamnestic questionnaire (the CHUSE). Acta Psychiatr Scand 1995;92:441-6.

15. Fielding R, Li J. A validation of the concept of current perceived health and the Current Perceived Health-42 (CPH-42) questionnaire. Qual Life Res 1997;6:35-42.

16. Piers EV. Piers-Harris Children's Self-Concept Scale: Revised Manual Los Angeles: Western Psychological Services, 1984.

17. Lefebvre AM, Arndt EM. Working with facially disfigured children: A challenge in prevention. Can J Psychiatry 1988;33:453-8.

18. Pertschuk MJ, Whitaker LA. Psychosocial adjustment and craniofacial malformations in childhood. Plast Reconstr Surg 1985;75:177-84.

19. Harter S. Manual for the Self-Perception Profile for Children. Denver: University of Denver, 1985.

20. Harter S. Self-Perception Profile for Adolescents. Denver: University of Denver, 1988.

21. Neemann J, Harter S. Manual for the Self-Perception Profile of College Students. Denver: University of Denver, 1986.

22. Harter S, Pike RG. The Pictorial Scale of Percieved Competence and Social Acceptance for Young Children. Denver: University of Denver Press, 1980.

23. Shealy AH. Self-esteem in Children with Attention Deficit Hyperactivity Disorder. Birmingham: University of Alabama, 1989.

24. Killeen MR. Parent influences on children's self-esteem in economically disadvantaged families. Issues Ment Health Nurs 1993;14:323-36.

25. Hinshaw SP, Han SS, Erhardt D, Huber A. Internalizing and externalizing behavior problems in preschool children: Correspondence among parent and teacher ratings and behavior observations. J Clin Child Psychol 1992;21:143-50.

26. Hughes H. Measure of self-concept and self-esteem for children ages 3-12 years: A review and recommendations. Clin Psychol Rev 1984;4:657-92

27. Martini DR, Strayhorn JM, Puig-Antich J. A symptom of self-report measure for preschool children. J Am Acad Child Adolesc Psychiatry 1990;29;594-600 